\title{
"The world's most hostile environment": how the tobacco industry circumvented Singapore's advertising ban
}

\author{
M Assunta, S Chapman
}

Tobacco Control 2004;13(Suppl II):ii51-ii57. doi: 10.1136/tc.2004.008359

See end of article for authors' affiliations

Correspondence to: Mary Assunta, School of Public Health, Room 129A, Edward Ford Building (A27), University of Sydney, Sydney, NSW 2006 Australia; marya@ health.usyd.edu.au
S ingapore has one of the strongest tobacco control legislation in the world. Although it has much in common with its immediate neighbour Malaysia, there exist many differences as well. Tobacco control is one aspect where the difference between the two countries is stark. Singapore left the Federation of Malaysia to become an independent republic in August 1965. Under the 25 year leadership of Lee Kuan Yew, Singapore transformed from a third world island state to a "First World oasis" with the fourth highest per capita income in the world. ${ }^{1}$ Singapore ranks number 1 in world security and is ranked the least corrupt nation in Asia. ${ }^{1}$ It also has one of the lowest prevalences of smoking in the world ${ }^{2}$ with men at $24.2 \%$ and women, 3.5\%. ${ }^{3}$ In 1986 the government launched a long term, comprehensive national programme with the theme: "Towards a Nation of Non-Smokers." ${ }^{4}$

In Singapore, as in Malaysia, the industry is dominated by transnational tobacco companies. In Singapore Philip Morris has the largest share with $50 \%$ of the cigarette market. British American Tobacco (BAT) has 31\%, Japan Tobacco International (Thong Haut) 17\%, with other small companies having $2 \% .^{3}$ Land devoted to tobacco cultivation in Singapore dwindled over the years from 365 hectares in 1970 to nil today. Its leaf imports increased from 5688 metric tonnes in 1970 to 11288 metric tonnes in 2000. It still re-exports tobacco leaf, however the quantity has reduced over the years from 2019 metric tons in 1970 to 448 metric tonnes in 2000. ${ }^{3}$ Singapore's cigarette exports have increased from 1550 million sticks in 1970 to 27562 million sticks in 2000, indicating Singapore's role as a cigarette processing, production, and export centre for the Asia Pacific region. ${ }^{35}$

Singapore was one of the first countries to implement a comprehensive tobacco control programme. Its first legislation on smoke-free public places was implemented in 1970 and it was the first country to ban tobacco advertisements in 1971..$^{6}$ Descriptors such as "draconian" and "hostile" are repeatedly used by the industry to describe Singapore's tobacco control laws. The industry was concerned that "Singapore has become the world's most hostile environment for our industry", having "...one of the world's most restricted markets". ${ }^{9}$ While the tobacco industry was aware that the government's position on tobacco was unrelenting ${ }^{10}$ they were nevertheless able to operate a successful tobacco business. According to RJ Reynolds: "Aggressive industry pricing has also made Singapore the most profitable market in the world..."

This paper examines how the tobacco companies conducted their business in this hostile environment and attempted to counter some of the Singapore government's tobacco control measures.

\section{METHODS}

This paper is based on tobacco industry document searches conducted on the Master Settlement Agreement websites between August and October 2002: http://www. tobaccoarchives.com/. Additional searches were conducted on secondary document collection websites including Tobacco Control Archives, ${ }^{11}$ British Columbia's Tobacco Industry Documents, ${ }^{12}$ and Tobacco Documents Online. ${ }^{13}$ To facilitate systematic document analysis initial searches focused on geographic terms representative of Singapore. Search words incorporated synonymous terms representative of the concept, acronyms, abbreviations, variations of spelling, etc. The searches resulted in 2782 documents, which were then sorted by date and evaluated according to their degree of importance. During this process, the metadata for documents between 1970 and 2000 considered to be of high value were screened for further clues to conduct subsequent searches. The technique of snowballing was then used where terms from the metadata were formulated into new searches to run on the industry and secondary sites. For details refer to: http://tobacco. health.usyd.edu.au/site/gateway/docs/pdf/ Singapore_Search_Strategy.pdf.

Lack of accessibility to BAT documents from Guildford is a

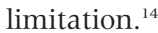

Abbreviations: BAT, British American Tobacco; STC, Singapore Tobacco Company; T/N, tar/nicotine; USIB, US international brands 


\section{RESULTS}

\section{Singapore government's anti-smoking stance}

In 1970, $42 \%$ of Singapore's men and $4.5 \%$ of its women smoked. ${ }^{6}$ Tobacco use per person in Singapore in 1970 was $2.5 \mathrm{~kg}$, which had reduced to $1.5 \mathrm{~kg}$ per person in $1991 .{ }^{15}$ Smoking prevalence began a downward trend in the 1970s, continuing through the 1980s. It decreased from $22 \%$ in 1983 to $19.8 \%$ in 1985 to $17.5 \%$ in $1987 .{ }^{16}$ Since 1979 , the Training and Health Education Department of the Ministry of Health has systematically organised public information programmes on smoking. ${ }^{6}$ In 1996, a Committee on Smoking Control was formed to direct the National Smoking Control Programme. ${ }^{17}$ The latest measures implemented by the government include banning the sale of small packs of cigarettes with less than 20 sticks, graphic warnings on packs, ${ }^{18}$ and taxing cigarettes by sticks rather than weight. ${ }^{19}$ Currently Singapore has one of the lowest adult smoking prevalence in the world at $14 \%$ in a population of about 3.5 million. $^{7}$

In 1987, Philip Morris reported "Four out of five smokers were aware of the Government's Anti-Smoking Campaign in the past year. ...some of them cut down the number of cigarettes they smoked in a day" ${ }^{16}$ Philip Morris saw itself in Singapore as being "...in the same boat as U.S. tobacco companies: With smoking declining in their home markets, they must look abroad for customers". ${ }^{15}$ Singapore was still important to the tobacco business. BAT, for example, in the mid 1990s had increased its earnings by $15 \%{ }^{15}$

In 1982, Philip Morris observed the industry in Singapore might be vulnerable to closure: "As there are labor shortages and the tobacco industry is under constant attack, it is not felt that the Government would object to closing down the industry." ${ }^{\prime 20}$ Since smoking prevalence was decreasing in Singapore, increasing sales and arresting further tobacco control were a challenge. However, Philip Morris knew any approach to the government to "...relax its regulation on the industry or to refrain from excessive taxation would have the opposite effect". ${ }^{21}$ It observed in 1993 a combination of three factors had caused consumption to decline by an unprecedented 8\%: “...the hefty price hike of S\$0.70/pack...the ban on possession and/or smoking of cigarettes by under-18s implemented on May 31 this year and a smoking ban on uniformed military personnel." ${ }^{22}$ The action plan to address declining consumption focused on emphasising the product “...ensuring their wider availability and visibility, with greater emphasis on smaller pack variants".22

\section{Advertising cigarettes to Singaporeans through Malaysian media}

In March 1971, Singapore banned all tobacco advertisements and in 1989 amended the Smoking (Prohibition on Advertisements) Act to prohibit free sampling, point-of-sale display, and cigarette logos on non-tobacco products. With this amendment all forms of logo advertising were prohibited and tobacco products could no longer be offered as prizes or gifts. The chairman of BAT commented: "The legislation is so broad that it has no clear definition of advertising. ... Under the strict interpretation of the Act, I can't even give you my name card." 4

The prohibition on advertising, however, did not prevent the tobacco companies from advertising cigarettes to Singaporeans. In 1980, when planning its five year programme, Philip Morris identified Malaysian television as an advertising opportunity: "The continuing availability of television in Malaysia, at least until 1982, will provide us with the opportunity to continue to exploit the "spillover" effect of Malaysian television into Singapore, to build Marlboro awareness and assist in attracting new users." ${ }^{23}$ It would thus "Circumvent the Singaporean cigarette advertising ban..." noting "Additional funds allocated will ensure that Marlboro remains visible on Singapore television". ${ }^{23}$

Philip Morris noted: "Malaysian T.V. channels RTM 1 and RTM 2 are received by most S'pore households.... S'pore D.M.E. [Direct Marketing Expenditure] directed into this source, tied into selective programming and supported by a strong publicity campaign in S'pore could provide our brands with good advertising support." ${ }^{24}$ In its plans for the period between 1992 and 1996, STC forecasted how its competitor's brands would perform using Malaysian television. ${ }^{25}$

When Singapore banned parallel advertising of cigarette brand names on non-tobacco products in July 1986 it affected Philip Morris' Marlboro Country Campaign. ${ }^{26}$ When Philip Morris evaluated its performance for the 1981-85 period it aimed, "To overcome limitations on advertising ban through increased frequency over Malaysian network" ${ }^{27}$ It noted it had failed to obtain more spots from the Malaysian TV network and hence planned to continue working towards that objective. ${ }^{27}$ The Singaporean authorities were aware of Malaysian television being used by the companies to circumvent the advertising ban in Singapore. According to a 1980 Brown \& Williamson document, one way the government addressed this issue was to "...threaten to require pack warning if TV cigarette advertising exposure from Malaysia increased". ${ }^{28}$ In late 1980, pack warnings were implemented. ${ }^{29}$

Under a total tobacco advertising ban one would expect industry advertising expenditure to reduce over the years. The reverse was true for Singapore. In 1988, according to Philip Morris: "Whereas the Industry was spending less than US\$3.0 million per year in this area as recently as the early 80 's, today it spends over US\$15.0 million in a frantic scramble for ever contracting opportunities that in turn geometrically increase the cost of the few opportunities still available." ${ }^{\prime 30}$

While BAT publicly claimed to comply with the laws and regulations of the country it was operating in, ${ }^{31}$ they continued to use alternate means to advertise to Singaporeans by what they referred to as "offshore" strategy. $^{32}$ In 1990 the Singapore Tobacco Company (STC), BAT's local subsidiary, reported exploiting cross border advertising opportunities to BAT UK:

\section{"The advertising and promotion ban is the most draconian in the world and there is literally nothing we can do in this regard in a domestic context... This leaves us only offshore support and here again we are in a weak position. We were the first to exploit opportunities in Johor Bahru [neighbouring Malaysian city] and Batam [Indonesian town]..."33}

Similarly in an earlier example STC reported: "Singapore have contributed S\$100K to the ' 89 activity. STC have agreed with MTC [Malaysian Tobacco Company] to develop the event [Grand Prix in Malaysia] into a 'larger affair' and more fully exploit the opportunity." ${ }^{\prime \prime 4}$ Besides using Malaysian television, the ever opportunistic STC also used "high rise" billboards across the causeway in Johor Bahru in Malaysia. ${ }^{32}$

The STC was conscious that its offshore advertising could result in governmental action. In April 1993, an STC executive expressed concern to BAT UK over promotional activities, which contravened the law and could cause them embarrassment: "This broadly covers a number of activities currently undertaken and/or costs incurred by STC which I believe could be considered as inconsistent with Singaporean regulations which if brought to light could cause embarrassment or worse. Singaporean law clearly states that no activity may be undertaken nor cost incurred that promotes the sale of cigarettes." 35 
The executive identified four areas that "...could be perceived as contravening the law" including "Our upweighting of MTC's media spend", "Regional contribution to IB [International Brand] activities" and "fees in respect of marketing support and consumer research". ${ }^{35}$ In a 1994 document on BAT's evaluation of sponsorship exploitation plans such as using other companies, it reports: "In a restricted environment, STC manages creative exploitation through Motul" [French company manufacturing motor oil] and rated it as "good". ${ }^{36}$

The STC wanted to avoid any government investigation, which could expose a wider range of these activities: "Should any of the issues be raised at the official level, it could easily instigate an investigation that would or could reveal the others. In any case, it could lead to a loss of credibility and severely harm our relationship and standing with government." ${ }^{\prime 35}$ The executive recommended the termination of these activities: "it is our belief that the risks heavily outweigh the benefits and thus should be terminated." ${ }^{35}$

BAT UK's response to this concern, however, was to advise better housekeeping and for "... some suitable changes to terminology and descriptions" to be used. ${ }^{37}$ The arrangement was to work with "...MTC to determine a suitable vehicle for accomplishing reimbursement". ${ }^{37}$

For the remainder of the decade, between 1994 and 1999, a BAT document on Singapore's key brand plans projects STC's increasing advertising expenditure (table 1). It also refers to an increase in advertising expenditure for Kent on Malaysian television in $1995 .^{38}$

Such was the importance of brand publicity that BAT was prepared to create and benefit from negative publicity by creating a misleading claim with its Barclay brand. It planned to orchestrate the complaints against the misleading claim and then to rectify it while milking the ensuing publicity. In 1995, BAT noted Barclay's "Brand awareness is very low and the positioning of the brand is not clear to most consumers". ${ }^{38}$ It planned to: "Re-launch the Actron and Menthol variants using the '99\% TAR FREE' claim on the pack and tear tape...Provoke the competitors to lodge a complaint against the use of this claim or organise 'spontaneous' negative letters from consumers to the editors of the major newspapers. Generate debate and coverage (even if it is negative) in the press and on television about the claim. Withdraw the claim and replace with 'Ultra Low Tar' if forced to do so." ${ }^{\prime 38}$

\section{Launching a new cigarette brand in an "extremely stifling'"39 environment: the Alpine story}

In 1988 Philip Morris circumvented the ban on advertising when introducing a new brand, Alpine, into the Singapore market by first launching a wine cooler with the same name. The wine cooler targeted at an audience of the same age group as the market for Alpine so that they would recognise the brand name when the cigarette later entered the market: "Due to this government restriction, we will be using a brand diversification strategy to create awareness and visibility for

\begin{tabular}{|c|c|c|c|c|c|c|}
\hline & 1994 Est & 1995 & 1996 & 1997 & 1998 & 1999 \\
\hline $\begin{array}{l}\text { Total spend } \\
\% \text { ATL* }^{*}\end{array}$ & $\begin{array}{l}980 \\
49 \%\end{array}$ & $\begin{array}{l}1540 \\
58 \%\end{array}$ & $\begin{array}{l}1790 \\
69 \%\end{array}$ & $\begin{array}{l}2000 \\
71 \%\end{array}$ & $\begin{array}{l}2050 \\
70 \%\end{array}$ & $\begin{array}{l}2100 \\
70 \%\end{array}$ \\
\hline$\%$ BTL & $51 \%$ & $42 \%$ & $31 \%$ & $29 \%$ & $30 \%$ & $30 \%$ \\
\hline \multicolumn{7}{|c|}{ Share of own spend } \\
\hline LSF & $60 \%$ & $44 \%$ & $52 \%$ & $56 \%$ & $56 \%$ & $56 \%$ \\
\hline Kent & $40 \%$ & $53 \%$ & $45 \%$ & $43 \%$ & $44 \%$ & $44 \%$ \\
\hline Barclay & & $3 \%$ & $3 \%$ & $1 \%$ & - & - \\
\hline
\end{tabular}

the Alpine brand name. We plan to accomplish this objective by introducing a wine cooler called Alpine...The wine cooler campaign will run approximately four to six weeks prior to our cigarettes introduction which is planned for September 1, 1987." ${ }^{\prime 40-42}$

Philip Morris anticipated the authorities' questioning the promotions, and planned their defence: "In this exercise the risk of falling foul of the authorities... exists as in all other cigarettes advertising and promotions. For example the technically legal "High Country Tours" sponsorship of the World Cup telecasts was ultimately censured, but not until after the sponsor gained tremendous advertising value. Government enquiries after the launch of 'Alpine' cigarettes can be expected. Although a case may be made based on the fact that 'Alpine' wine cooler is a bona fide business venture, the case would be more credible if 'Alpine' wine cooler was marketed successfully elsewhere." ${ }^{\prime 39}$ Alpine cigarettes were launched in Singapore in 1988.

In 1989 Philip Morris ranked the launch as the most potent in the local tobacco sector in a decade: "Within the scope of what is virtually a total ban over any A\&P [advertising \& promotion] activity for cigarettes in Singapore, the Alpine launch program during the period September - October 1988 was certainly the most impactful launch of a cigarette over the past 10 years. In terms of awareness and interest generation leading to mass trial and re-trial, it was a success." ${ }^{\prime 3}$ Focus group research with consumers elicited: "Mr Alpine 'has a class above Salem'; 'He drives a Porsche, Ferrari, fast sports car'; 'He is in control of his women'; ...'He is rich or His father is wealthy'.$^{\prime \prime 44}$ (emphasis in original).

\section{Reaching out to the young: government versus industry}

BAT and Philip Morris have been running campaigns in many countries claiming children should not smoke. Yet in the early 1980s STC was concerned about anti-smoking campaigns in schools. In 1983, the Singapore Tobacco Manufacturers \& Importers Association identified: “...strong anti smoking programmes in schools, resulting in children persuading their parents to cease smoking" ${ }^{\prime 45}$ as one of the main threats facing the tobacco industry. In 1986 one of the key issues Philip Morris addressed was "The continuous Government anti smoking campaign at secondary schools and junior colleges" which it identified as a threat to its business. ${ }^{27}$ Philip Morris acknowledged that "Young smokers are an especially important target segment for the Singapore market..."16 because: "All the brands which have a young appeal...gained in smoker share. The gains are mainly attributable to the success of attracting new young smokers. Thus the younger groups who constantly are entering the market...must be carefully watched, and their current needs, wants, values, interests and activities monitored."16

In this light, it was disingenuous for the tobacco industry to sponsor an anti-smoking campaign focusing on children. In May 1990 the Tobacco Manufacturers and Importers Association distributed posters to be displayed at retail outlets. These read "Children, Don't smoke". Rather than endorsing the association's efforts, two days after the campaign was launched the Ministry of Health instructed the association to withdraw the posters with immediate effect. The reason given was: "The ministry's program is aimed not only at stopping children from smoking but focuses on youths [sic], that is all those below 30 years old. ${ }^{\prime \prime 4}$

STC forecasted that smoking by young people would fall between $1992-1996$ from $22 \%$ to $20 \%$ “....as a result of government sponsored anti smoking campaigns specifically targeted at youth". ${ }^{25}$ STC planned to arrest that forecasted decline by launching US international brands (USIB) of light cigarettes: "As the USIB lights segment growth will be 
mainly amongst young adults, ... Our objective is to increase segment share to $22 \%$ by $1996 . " 25$

\section{Innovative product, packaging, and display}

With a total ban on advertising and sponsorship the industry looked at special offers, better packaging and display as its last frontiers for promotion. Philip Morris, planning for its L\&M brand in 1988, proposed: "A buy 2 for the price of 1 proposition such as the 'More' offer in Malaysia would be a 'deal' that budget conscious Lucky Strike smokers would find difficult to resist." ${ }^{\prime 30}$

In 1991 the Singapore government pioneered global product display restrictions by limiting retailers to only one pack face per brand per variant and STC's response to this was to get creative about "... display units both large industry dispensers and smaller own brand ones". ${ }^{25}$ STC, for example, planned to "Implement new approved pack designs to enhance shelf standout..." for its Lucky Strike Filter ${ }^{38}$ and introduce "...consumer sampling via special pack production aimed at increasing unit purchases" for both Lucky Strike and Kent. ${ }^{47}$

Philip Morris had also experimented using aroma and sweetened tipping paper in its cigarettes to target the health conscious young. It developed a special prototype in 1986 for its Alpine Menthol brand: "The aroma activated by tearing the tape...the consumer would not be aware of the mechanism by which the aroma was delivered and that the consumer would have the perception that the menthol aroma was derived from the product itself thereby denoting freshness. ${ }^{\prime 48}$ Between 1985 and 1987 Philip Morris developed a special cigarette for the young. Code named Project Byzantium, the new product, California, was "...more than just a menthol, it is the Pepsi of the menthol segment. ...California is casual \& carefree; it is fresh, free and fun. It is a world where the young people would like to be". ${ }^{49}$ Philip Morris conducted numerous consumer surveys on variations of its prototype that had a mentholated aroma and used sweetened tipping paper. ${ }^{50-52}$ Philip Morris was counting on the young's preferences for sweet tastes: "The only thing we don't know about the sweetener is the long-term effect-will they get tired of it? However, the target group that drinks Pepsi certainly don't get tired of sweet Pepsi. I think the younger generation is more 'tuned in' to 'sweet' than we are." $^{\prime \prime 53}$

Brown \& Williamson, which handled BAT's international brands, used public perception and product image to promote its brands when the public had misconceptions about a brand. The Kent brand, for example, was perceived by smokers as a "mild cigarette" although the company knew otherwise. An advertising brief for Kent illustrates that the company proposed using the public misconception and to position Kent through point of sale advertisements as a US cigarette which: “...offers smokers health and social reassurance. A young, thriving brand identified with a modern free life style, smoked by sensible people who know how to get the most out of life." ${ }^{\prime 54}$ It was also seen as a more feminine brand and the smoker: "... an upscale, white-collar person who is young, easy going, and gentle adult. The white pack is unique and is consonant with the product and smoker perceptions." ${ }^{55}$

A Philip Morris consumer survey in Singapore in 1987 had shown: "Two out of three smokers believe that lower $\mathrm{T} / \mathrm{N}$ [tar/nicotine] cigarettes are less harmful to health, and that menthols have lower T/N." ${ }^{16}$ The survey had also shown: "A majority of smokers had no idea as to how 'Lights' is different from 'Milds'."16 Singapore's young were health conscious and the tobacco companies designed the packs of "Lights" to convey the idea of a safer cigarette. Philip Morris noted how: "In the absence of any $\mathrm{T} / \mathrm{N}$ information on either packs or
POS [point of sale] materials, the mentholated Salem with its cool, soothing draw came to be incorrectly perceived as a mild cigarette." $^{\prime 43}$ STC for example saw the value of "...a light shade of blue on the packaging instead of the current red color would better convey a 'lights' consumer perception" ${ }^{\prime 56}$ for its Kent cigarettes.

STC introduced smaller packs of 10s to appeal to "starters": "In order to ensure a better chance of success, we have decided to introduce Newport Lights 10's alongside Newport Lights $20^{\prime} \mathrm{s}$. We have determined that for a menthol variant, a starter's pack in $10^{\prime}$ s will aid in generating trial whilst creating an impact which would otherwise be absent.." ${ }^{57}$

STC also experimented with “...LSF [Lucky Strike Filter] Glow-in-the-dark and Hologram packs, and 'Kent Clear' with $60 \%$ less side stream, in a transparent pack" ${ }^{58}$ For its key brands in 1995, STC planned to "Implement secondary sampling campaign (glow-in-the-dark, hologram and temperature change packs) to generate word-of-mouth, get consumers to take a new look at LSF and shift image towards innovative and dynamic." ${ }^{\prime \prime 8}$

\section{Lobbying government on labelling and health warnings}

After the Singapore government imposed a total ban on all forms of tobacco advertising in March 1971, the Minister of Culture had announced "...if advertising on Malaysian TV received in Singapore was increased, further legislation would be imposed-i.e. warning labels on packets in four languages". ${ }^{59}$ In the late 1970s the issue of health warnings re-emerged. In March 1979 the Singapore tobacco industry sent a joint memorandum to the authorities on the proposed health warning on cigarette packs. Their arguments closely resembled those used by the industry elsewhere: smoking causing disease "remains an open question"; "Warnings are customarily not applied to products which may or may not have long-range peripheral or detrimental side-effects: for example eggs, butter..."; and "... frequent use of warning labels, where the warning does not appear to be warranted, would serve to dilute the effectiveness of legitimate warnings on products of known danger" ${ }^{\prime 60}$ This memo conceded that, should the Ministry proceed with the proposal, the warning should be "Warning by Singapore Government: Smoking can damage your health" and should appear on the side panel. ${ }^{60}$ The Singapore Government implemented this proposed warning in November 1980, placing it on the front panel of the pack. ${ }^{8}$

In 1979 the government also wanted tar and nicotine yields to appear on cigarette packs. The industry position was: "We strongly oppose printing this info on packs (in as, etc) and have agreed with other ICOSI [International Council on Smoking Issues] to resist such imposition." ${ }^{\prime 61}$ The industry prepared a memo for the Singapore government outlining cooperation to reduce delivery levels of cigarettes marketed in Singapore. The memo made a case for why "condensate" should not be "erroneously" referred to as "Tar", that there are various definitions for "condensate", how its ratings can vary from time to time, and that consumers are unfamiliar with the term. As for nicotine, it stated, “...the quantities absorbed by smoking is [sic] generally acknowledged not to present a health problem" ${ }^{62}$ The industry did not indicate that in its own documents, it freely used the term "Tar". ${ }^{63}$ The industry was building a case for why it did not want regulations on "Tar" and nicotine levels, recommending instead that consumers' subjective appraisals of different brands in the absence of any labelling should be the policy adopted: "...the decision is entirely in the hands of the consumers themselves. What the industry can do is to continue offering smokers a wide choice of brands with varying levels of deliveries including mild brands." ${ }^{62}$ 
In 1988, the Ministry of Health proposed rotational health warnings on the packs and the Tobacco Manufacturers' Association of Singapore responded to this proposal by objecting particularly to two of the proposed warnings: "smoking kills" saying warnings "...should be of a factual, and not of an emotional, nature". And on "smoking is addictive" saying "...there is considerable evidence that cigarette smoking is not an addiction" ${ }^{\prime 64}$ (emphasis in original). The Ministry had also proposed limits on nicotine and tar to which the industry responded: "Sudden changes in delivery levels and, therefore, taste can distort consumer preferences and alter consumer behaviour in ways outside Government control. Indeed international health authorities have warned (against a sudden reduction in 'tar' and nicotine levels)" ${ }^{\prime 64}$ (emphasis in original).

In January 1989, the Philip Morris office in New York advised the Singapore office on additional arguments that could be used to counter the health warning proposal. These included a novel rationale for placing the warnings on the side panel of the cigarette pack because: "...there is no reason to believe side panel warnings are ineffective. In fact consumers are most likely to heed warnings that are not 'forced upon them."'65 The New York office also pointed out that "It is more of a political question of how forcefully you want to reiterate these arguments". ${ }^{65}$ It further recommended the use of warnings from Australia because "...the warning box in Australia is smaller $(15 \%)^{\prime \prime}{ }^{65}$

In December 1989, the Singapore government ruled that four rotational health warnings were to be placed on cigarette packs, occupying $20 \%$ of the pack face. The warnings were: "smoking causes cancer", "smoking causes heart disease", "smoking damages your lungs", and "smoking harms those around us". ${ }^{8}$ It also announced that packs would have to specify tar and nicotine levels which were set at not more than $15 \mathrm{mg}$ and $1.3 \mathrm{mg}$, respectively. This measure went into force in October 1989.

The RJ Reynolds office in Singapore also reported this development to its head office and drew particular attention to passive smoking related warning, noting it had "....registered its objection to this warning on the grounds that no clear scientific link has been established". ${ }^{10}$ In its place it suggested a qualified amenity based warning "Smoking may annoy those around us". ${ }^{10}$

In 1993, the government moved to revise the health warnings, introducing "Smoking kills" and "Smoking harms your family". STC wrote to BAT in the UK reporting "We are contesting this but see little hope of success." ${ }^{166}$ RJ Reynolds International sought the help of the Singapore Embassy in Washington and the US Trade Representative when it failed to secure an extension for the implementation of new pack health warnings with the Singapore authorities. While the embassy officials were sympathetic, they were not optimistic of an extension because "tobacco was involved". ${ }^{67}$ RJ Reynolds then turned to the US Trade Representative to use trade as leverage when it learnt that "...Singapore has not yet filed the new labeling regulations with the GATT secretariat, as they are required to do under the technical barriers to trade agreement. Although we do not have effective recourse against them, it is still a breach of the agreement on their part, and at the very least it will cause them some embarrassment." ${ }^{\prime 67}$ The industry was successful in obtaining the extension and the implementation date was pushed from 1 January 1994 to June $1994 .{ }^{68}$

\section{Boycotting businesses that support government anti- smoking campaigns}

The tobacco industry monitored and evaluated the government's anti-smoking campaign, particularly during the month long campaign for World No Tobacco Day in 1995.
BAT also paid attention to third parties who sponsored the campaign. ${ }^{69}$ BAT recommended: "Konica's sponsorship of these banners is a direct attack on our industry... STC will stop using Konica products with immediate effect...We are proposing that the BAT Group should also stop using Konica products in support of STC...Konica HQ (Japan) will be notified of our action. ${ }^{\prime 69}$ The intention for the boycott was to "...extend the boycott worldwide until Konica ceases their sponsorship of anti-smoking activities". ${ }^{69}$ While the tobacco industry outwardly "supported" the government's campaign on youth smoking by distributing its posters to retailers, these documents plainly illustrate its aggression toward other businesses that engaged in any meaningful cooperation with government anti-smoking initiatives.

\section{DISCUSSION}

Singapore serves as a good example of how tobacco control measures were resolutely implemented because the head of state had a firm stand and a long term vision to establish a smoke-free society. The industry documents on Singapore illustrate how the tobacco industry adapted itself and conducted business in a country with the "most draconian" ban on advertising and promotions in the world. It circumvented the law to promote its products and rehashed arguments used elsewhere to substantiate its claims.

The tobacco industry's response to printing of tar/nicotine levels and health warnings on packs in Singapore, for example, was consistent with its position elsewhere which is to delay, weaken, or avoid labelling for as long as it can. ${ }^{70}$ However, the government's persistence in legislating more effective labelling resulted in the industry acknowledging they had little leverage with the government when tobacco was involved. Singapore became the first country in Asia to implement rotational graphic health warnings as of 1 August 2004. ${ }^{71}$ Philip Morris has announced it is voluntarily providing information inserts on health risks of smoking in packs in Switzerland, Australia, New Zealand, and Malaysia. ${ }^{72-74}$ The information it is now willing to provide is a departure to what the industry collectively denied the previous decades. This can be interpreted as an effort to preempt legislation on graphic warnings in line with provisions in the Framework Convention on Tobacco Control. ${ }^{75}$

Comparing tobacco control efforts between Singapore and Malaysia suggests several factors explaining Singapore's successes in achieving an adult smoking prevalence of $14 \%$ compared with Malaysia's 25\%. Firstly the Singapore government had a clear policy to curb smoking, protect non-smokers, reduce tobacco consumption, help smokers quit, and prevent young people from taking up smoking. It put serious effort into enacting legislation as early as 1970, strictly enforcing legislation and carrying out public health education programmes. Malaysia did not have a comprehensive national policy on tobacco control. Malaysia's efforts in the last 30 years were more ad hoc, favouring industry guidelines over legislation. While the Malaysian government discouraged smoking, it also protected tobacco cultivation and provided an environment to encourage the industry. The first broad tobacco control legislation in Malaysia was passed in 1993.

In Singapore, the government decided on the course of action, announced it and implemented it unreservedly. For example, when the Singapore government decided to ban tobacco advertisements in 1971, the tobacco industry was not involved in any consultation process. BAT referred to the government's action as "short circuiting" the stage a country normally goes through when moving from total freedom to advertise, to a complete ban. ${ }^{76}$ In the case of Singapore, there were no stages involved and the ban was outright unlike 


\section{What this paper adds}

This is the first paper reviewing internal tobacco industry documents pertaining to Singapore, which illustrate how the tobacco industry responded to the stringent tobacco control enacted by the Singapore government.

Malaysia, which went through the various stages of guidelines and levels of restrictions as outlined by BAT. ${ }^{77}$

Singapore's actions were uncompromising, sending a clear anti-smoking message to both the public and the tobacco industry. Bans on smoking in public places and tobacco advertising bans were substantial with no obvious loopholes. For example, when the government banned smoking in public places which focused on cinemas, theatres, and buses in 1970, over a period of 18 years the Prohibition of Smoking in Certain Places Act had been amended nine times to include more public places. Enforcement was vigorous. In Malaysia bans on smoking in public places have had three amendments and smoking is allowed in one section of air conditioned restaurants. Similarly the Singaporean ban on tobacco advertising, sponsorship, and promotions was total with no exemptions. By contrast, Malaysia has the reputation for allowing extensive indirect advertising and sponsorship by tobacco companies. ${ }^{78}$

Singapore Ministry of Health's rejection to offers of help from the Tobacco Association to "prevent the public receiving confusing or contradictory messages in our smoking control efforts" ${ }^{\prime 79}$ provides a valuable lesson in the current climate of tobacco industry sponsored youth smoking prevention programmes worldwide. When the Singapore government was convinced the industry was misleading the public and children by distributing its posters to tobacco retailers, it issued an immediate order for their withdrawal. This order was not open to discussion and the government refused attempts by the tobacco industry to meet with it. Tobacco legislation in Singapore now requires the industry to obtain permission from the Health Minister to be acknowledged in

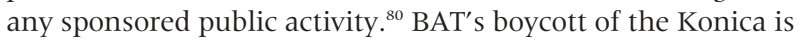
consistent with the way the tobacco industry reacted with aggression against other business that supported smoke-free campaigns elsewhere. ${ }^{81}$ Currently there are no tobacco industry sponsored youth smoking prevention programmes in Singapore. ${ }^{82}$

In 1990, BAT Singapore's chairman had remarked on Singapore's advertising bans: "I just think it's likely that people will look back in the year 2000 and say that the measures they chose (to discourage smoking) were extremely ineffective. Nowhere in the world where they have put in advertising bans has there been any identifiable reduction in consumption." ${ }^{4}$ Singapore's declining consumption over the period in which it implemented tobacco control measures, to currently having among lowest adult smoking prevalence in the world, suggests otherwise.

\section{ACKNOWLEDGEMENTS}

Thanks are due to Fiona Byrne for her invaluable information management and input, and reviewers for their comments. The research presented in this paper is supported by grants from the National Health \& Medical Research Council, Australia, (20012003\#153857) and the US National Institutes of Health (20012005\#R01 CA87110-01A1)

\section{Authors' affiliations}

M Assunta, S Chapman, School of Public Health, University of Sydney, Sydney, NSW, Australia

\section{REFERENCES}

1 Skousen M. From poverty to riches: is there a magic elixir? Jul 2002. http:// www.mskousen.com/Books/Articles/0207elixir.html [Accessed 22 Oct 2002].

2 Singapore Health Promotion Board. Singapore signs World Health Organization Framework Convention on Tobacco Control: [press release] 6 Jan 2004. http://www.hpb.gov.sg/hpb/cor/cor040131.asp [Accessed 13 Jul 2004].

3 Shafey O, Dolwick S, Guindon GE, eds. Tobacco control country profiles, 2nd ed. Atlanta: American Cancer Society, 2003:356.

4 Lewis M. Tobacco marketers face shrinking media options. Asian Advertising \& Marketing 1990 Aug:34.

5 Corrao MA, Guindon GE, Sharma N, et al. eds. Tobacco control country profiles: regional summary for the Western Pacific Region. Atlanta, Georgia: The American Cancer Society, Inc, 2000.

6 World Health Organization. Tobacco or health: a global status report. Geneva: WHO, 1997:482-5.

7 Goh CT. Speech by Prime Minister Goh Chok Tong at the launch of the National Healthy Lifestyle Campaign 2002 on Monday, 2 September 2002, at $4.00 \mathrm{pm}$, at Singapore International Convention and Exhibition Centre, Suntec City, Level 2 Ballroom. 2002. http://www.gov.sg/singov/announce/ 020802pm.html [Accessed 22 Oct 2002].

8 RJ Reynolds. Singapore market update. 1993. R.J. Reynolds. Bates No. 513055689/5700. http://legacy.library.ucsf.edu/tid/tao23d00.

9 Barnes J. Management visit to Asia Pacific. 18 Apr 1995. R.J. Reynolds. Bates No. 513214462/4640. http://legacy.library.ucsf.edu/tid/jin30d00.

10 Mathews PL. ETS. 2 Feb 1989. RJ Reynolds. Bates No. 506816596. http:// legacy.library.ucsf.edu/tid/bzs54d00.

11 University of California, San Francisco. Tobacco control archives. UCSF. http://www.library.ucsf.edu/tobacco/.

12 British Columbia's Tobacco Industry Documents. http:// www.moh.hnet.bc.ca/cgi-bin/guildford_search.cgi.

13 Tobacco Documents Online. http://tobaccodocuments.org.

14 Lee K, Gilmore AB, Collin J. Looking inside the tobacco industry: revealing insights from the Guildford Depository. Addiction 2004;99:394-7.

15 The Plain Dealer Cleveland Ohio. Singapore is cracking down on smoking 8 Jan 1995. Philip Morris. Bates No. 2072007560/7561. http:// legacy.library.ucsf.edu/tid/dyb08d00.

16 Philip Morris Asia Inc. Singapore GCS 1987. 28 Mar 1988. Philip Morris. Bates No. 2504046948/6994. http://legacy.library.ucsf.edu/tid/ xbv19e00.

17 Singapore Health Promotion Board. National Smoking Control Programme (NSCP). http://www.hpb.gov.sg/hpb/default.asp?pg_id = 1030 [Accessed $21 \mathrm{Jul} 2004$ ].

18 Ting LH. Singapore's war-on-smoking campaign is about to enter a new phase. The Straits Times (Singapore) 2 Sep 2002. LexisNexis - All News [Accessed 17 Dec 2002.

19 Anon. Cigarette cost more after change in tax system. The Star (Malaysia) $4 \mathrm{Jul}$ 2003. http://thestar.com.my/news/story.asp?file =/2003/7/4/asia [Accessed 4 Jul 2003].

20 Murray R. Singapore: [excerpt from the RTH Committee Meeting Venice] 14 May 1982. Philip Morris. Bates No. 2023275395. http:// legacy.library.ucsf.edu/tid/zwu71 foO.

21 Verkerk HG. H.G. Verkerk - Report on visits to Pakistan, India, Philippines and Singapore (November 24 - December 9). 9 Dec 1984. Philip Morris. Bates No. 2023272527/2530. http://legacy.library.ucsf.edu/tid/tzu71fo0.

22 Philip Morris. 3YP 1994-96 Singapore. 11 Oct 1993. Philip Morris. Bates No. 2504008305/8371. http://legacy.library.ucsf.edu/tid/vha42e00.

23 Philip Morris Asia Inc. Five year plan 1981-1985. Nov 1980. Philip Morris Bates No. 2504017362/7424. http://legacy.library.ucsf.edu/tid/tux32e00.

24 Philip Morris. Agenda of strategic issues - Singapore. 1986. Philip Morris. Bates No. 2504047553/7568. http://legacy.library.ucsf.edu/tid/ hbv19e00.

25 BATCo Singapore. Corporate plan 1992-1996. 1991. British American Tobacco. Bates No. 304534348/4365. http://tobacco.health.usyd.edu.au/ tds/BAT304534348_4365 [Accessed 15 Sep 2002].

26 Philip Morris. Update for June Meeting. May 1986. Philip Morris. Bates No. 2023267800/7805. http://legacy.library.ucsf.edu/tid/tos98e00.

27 Philip Morris. Macroenvironment summary. 1986. Philip Morris. Bates No. 2504011708/1735. http://legacy.library.ucsf.edu/tid/xnv19e00.

28 Brown \& Williamson International Tobacco. Market Summary: Singapore. undated. Brown \& Williamson. Bates No. 660924894/4904. http:// legacy.library.ucsf.edu/tid/rxd80f00.

29 RJ Reynolds. Singapore. Nov 1986. R.J. Reynolds. Bates No. 506825783/ 5785. http://legacy.library.ucsf.edu/tid/iyr54d00 [Accessed 15 Sep 2002]

30 Dollisson J. Strategic marketing issues - Singapore. May 1988. Philip Morris. Bates No. 2504047569/7575. http://legacy.library.ucsf.edu/tid/ cbv19e00

31 British American Tobacco. BATCo answers to allegations/statements contained in the WDM "tobacco" briefing document. 1982. British American Tobacco. Bates No. 201083975/3982. http://tobacco.health.usyd.edu.au/ tds/BAT201083975_3982 [Accessed 15 Sep 2002].

32 BATCo. Market presentation/business review Singapore domestic. Mar 1992. British American Tobacco. Bates No. 301630691/0727. http:// tobacco.health.usyd.edu.au/tds/BAT301630691_0727 [Accessed 21 Aug 2002].

33 Ross I. Marketing guidelines. 13 Jul 1990. British American Tobacco. Bates No. 301630841/0842. http://tobacco.health.usyd.edu.au/tds/ BAT301630841_0842 [Accessed 21 Aug 2002] 
34 Sweeney WM. Far east marketing directors regional meeting Singapore, 22nd and 23rd June 1989. 9 May 1989. British American Tobacco. Bates No. 400896822/6839. http://tobacco.health.usyd.edu.au/tds/ BAT400896822 6839 [Accessed 21 Oct 2002]

35 Manning J. [Letter from JCD Manning to PN Adams]. 23 Apr 1993. British American Tobacco. Bates No. 500014609/4610. http:// tobacco.health.usyd.edu.au/tds/BAT500014609_4610 [Accessed 15 Sep 2002].

36 British American Tobacco. Lucky Strike - New TLS Campaign. 20 May 1994 British American Tobacco. Bates No. 303590410/0491. http:// www.library.ucsf.edu/tobacco/batco/html/600/683/ [Accessed 21 Oct 2002].

37 Adams PN. [Letter from PN Adams to JCD Manning]. 5 May 1993. British American Tobacco. Bates No. 500014608. http:// tobacco.health.usyd.edu.au/tds/BAT500014608 [Accessed 15 Sep 2002].

38 BATCo Singapore. Singapore 1995 key brand plans. 20 May 1995. British American Tobacco. Bates No. 500282637/2641. http:// tobacco.health.usyd.edu.au/tds/BAT500282637_2641 [Accessed 21 Oct 2002].

39 Philip Morris. Alpine. 1985. Philip Morris. Bates No. 2504047687/7689. http://legacy.library.ucsf.edu/tid/nav19e00

40 Philip Morris. Alpine Wine Cooler Singapore. 1985. Philip Morris. Bates No 2504047668/7677. http://legacy.library.ucsf.edu/tid/lav19e00.

41 Philip Morris. Alpine Wine Cooler Singapore. 1985. Philip Morris. Bates No. 2504047678/7686. http://legacy.library.ucsf.edu/tid/mav19e00.

42 Schmidt P. Alpine project: Landor Brief (Draft). 22 Apr 1987. Philip Morris. Bates No. 2504047606/7611. http://legacy.library.ucsf.edu/tid/ wav19e00.

43 Jilla JH. The Alpine story. 25 May 1989. Philip Morris. Bates No. 2504047582/7586. http://legacy.library.ucsf.edu/tid/abv19e00

44 Consumer Probe (S) Pte Ltd. Project Marlboro/Salem - Jan/Feb '87 preliminary report based on 12 focus group discussions Singapore. Mar 1987. Philip Morris. Bates No. 2504047016/7025. http:// legacy.library.ucsf.edu/tid/asz32e00.

45 Verkerk HG. Visit to Malaysia, Singapore and Pakistan by HG Verkerk January 20-27, 1983. 14 Feb 1983. Brown \& Williamson. Bates No. 690157082/7084. http://legacy.library.ucsf.edu/tid/zto93f00.

46 Nathan F. Ministry wants 'Children, Don't Smoke' posters withdrawn. 29 May 1990. Philip Morris. Bates No. 2504061436 . http://legacy.library.ucsf.edu/ $\mathrm{tid} / \mathrm{nww} 32 \mathrm{e} 00$

47 British American Tobacco. [Singapore company plan excerpt]. 1993. British American Tobacco. Bates No. 500282784/2793. http:// tobacco.health.usyd.edu.au/tds/BAT500282784_2793 [Accessed 21 Oct 2002].

48 Snyder R. Alpine Menthol for Singapore. 7 Apr 1986. Philip Morris. Bates No. 2044440513/0514. http://legacy.library.ucsf.edu/tid/awm03e00.

49 Philip Morris. Project Byzantium. 1986. Philip Morris. Bates No. 2044364534/4537. http://legacy.library.ucsf.edu/tid/sjz82e00.

50 Tan P. Byzantium Product Test - Singapore. 25 Aug 1987. Philip Morris. Bates No. 2504046839/6841. http://legacy.library.ucsf.edu/tid/ocv19e00.

51 Jilla J. Byzantium Product Test. 27 Aug 1987. Philip Morris. Bates No. 2504046862. http://legacy.library.ucsf.edu/tid/blx32e00.

52 Liu A. Singapore Byzantium vs Salem Product Test. 15 Sep 1987. Philip Morris. Bates No. 2504046836/6838. http://legacy.library.ucsf.edu/tid/ ncv19e00.

53 Butson E. Project Byzantium. 7 Oct 1987. Philip Morris. Bates No. 2504046852. http://legacy.library.ucsf.edu/tid/ukx32e00.

54 Brown \& Williamson International Tobacco. Kent: Advertising brief. [undated]. Brown \& Williamson. Bates No. 621605119/5121. http:// legacy.library.ucsf.edu/tid/ogh90fo0.

55 Wilke FL. Topline summary: Kent parent perception/"Special Blend" pack qualitative research - Singapore, Malaysia, Hong Kong. 20 Apr 1987. Brown \& Williamson. Bates No. 670878897/8898. http://legacy.library.ucsf.edu/ $\mathrm{tid} /$ iny $60 \mathrm{fO} 0$.

56 Hamann MA. B\&W Trip Report. 24 Feb 1992. Brown \& Williamson. Bates No. 583227234/7236. http://legacy.library.ucsf.edu/tid/owp41 fo0.

57 Richards R. Newport Lights. 28 Feb 1992. Brown \& Williamson. Bates No. 597003451. http://legacy.library.ucsf.edu/tid/tli41fo0.

58 Richards R. [Minutes of meeting with Marcel Hamaan \& Pat Harper on 5/6/ 95, from R. Richards]. 12 Jun 1995. Brown \& Williamson. Bates No. 193000241/0243. http://legacy.library.ucsf.edu/tid/mvx03f00.
59 British American Tobacco. Growth of restrictions on the advertising and marketing of tobacco products worldwide. Feb 1977. British American Tobacco. Bates No. 301097275/7302. http://www.library.ucsf.edu/ tobacco $/$ batco $/ \mathrm{html} / 11300 / 11388 /$ [Accessed 15 Sep 2002].

60 Singapore Tobacco Industry. Singapore tobacco industry's views and recommendations on the proposed health warning on cigarette packs. 19 Mar 1979. Philip Morris. Bates No. 2024975006/5012. http:// legacy.library.ucsf.edu/tid/qsh24e00

61 Covington $M$. [Re your telex to $M J$ re meeting with Singapore Dept. of Trade] 21 Feb 1979. Philip Morris. Bates No. 2024950022/0024. http:// legacy.library.ucsf.edu/tid/lwq24e00 [Accessed 15 Sep 2002].

62 [Singapore Tobacco Industry]. Singapore tobacco industry suggestions on cooperation with government to reduce delivery levels of cigarette marketed in Singapore. 2 Nov 1981. R.J. Reynolds. Bates No. 502122126/2130. http:// legacy.library.ucsf.edu/tid/job29d00.

63 Brandon B. Critical export submitted \& report form brand name: Salem CPB84 Singapore. 9 Mar 1993. R.J. Reynolds. Bates No. 513170278/0321. http://legacy.library.ucsf.edu/tid/csi23d00.

64 The Tobacco Manufacturers' Association of Singapore. [Draft letter from the Tobacco Manufacturers' Association of Singapore addressed to the Acting Minister of Health]. Aug 1988. Philip Morris. Bates No. 2501048568/8571. http://legacy.library.ucsf.edu/tid/umx19e00.

65 Maerestetten C. Singapore Initiatives. 18 Jan 1989. Philip Morris. Bates No. 2024924138/4139. http://legacy.library.ucsf.edu/tid/lnd87e00.

66 Richards R. [Letter from R. Richards to D. Fell]. 8 Jul 1993. British American Tobacco. Bates No. 500180675. http://tobacco.health.usyd.edu.au/tds/ BAT500180675 [Accessed 21 Oct 2002]

67 Foreman D. Singapore health warning label. 8 Sep 1993. R.J. Reynolds. Bates No. 511409471 . http://legacy.library.ucsf.edu/tid/hdy43d00.

68 Clutterbuck JF. Rothmans International. Singapore- health warning. 22 Oct 1993. British American Tobacco. Bates No. 502649058/9059. http:// tobacco.health.usyd.edu.au/tds/BAT502649058_9059 [Accessed 21 Aug 2002].

69 Jurgens S. Singapore Tobacco Company. Singapore anti smoking month: a less effective campaign. 30 Jun 1995. British American Tobacco. Bates No. 502648933/8943. http://tobacco.health.usyd.edu.au/tds/ BAT502648933_8943 [Accessed 21 Oct 2002].

70 Chapman S, Carter SM. "Avoid health warnings on all tobacco products for just as long as we can": a history of Australian tobacco industry efforts to avoid, delay and dilute health warnings on cigarettes. Tobacco Control 2003;12(suppl III):iii13-22.

71 Lim J. Death to stare smokers in the face. The Straits Times (Singapore) 17 Jun 2004. http://straitstimes.asial.com.sg [Accessed 12 Jul 2004].

72 Quit Victoria. Graphic warnings on the front of cigarette packs the best way to inform smokers: [press release] 11 Mar 2004. http://www.quit.org.au/ index $2 . \mathrm{html}$ [Accessed $12 \mathrm{Jul}$ 2004].

73 Johnston M. Tobacco firm putting notes in packets. New Zealand Herald 30 Jun 2004. http://www.nzherald.co.nz/storydisplay. $\mathrm{cfm}$ ?storylD $=3575573$ [Accessed 12 Jul 2004].

74 Bernama. Philip Morris to launch info campaign on smoking hazards. Bernama (Kuala Lumpur) 7 Jul 2004. http://www.bernama.com [Accessed 8 Jul 2004]

75 World Health Organization. WHO Framework Convention on Tobacco Control. Geneva: World Health Organization, 2003, http://www.who.int/ tobacco/fctc/text/final/en/ [Accessed 12 Jul 2004].

76 British American Tobacco. Some guidelines for marketing tobacco products in the context of increasing restrictions on advertising. 1970. British American Tobacco. Bates No. 4061 14596/4606. http://www.library.ucsf.edu/ tobacco/batco/html $/ 2600 / 2680 /$ [Accessed 23 May 2002]

77 Assunta M, Chapman S. A mire of highly subjective and ineffective voluntary guidelines: tobacco industry efforts to thwart tobacco control in Malaysia. Tobacco Control 2004; 13(suppl II):ii43-50.

78 Assunta M, Chapman S. The tobacco industry's accounts of refining indirect tobacco advertising in Malaysia. Tobacco Control 2004; 13(suppl II):ii63-70.

79 Peralta C. Tobacco body's uphill battle. The Straits Times (Singapore). $17 \mathrm{Apr}$ 1995:4. LexisNexis - All News. [Accessed 7 Jan 2003].

80 Singapore. Smoking (Control of Advertisement and Sale of tobacco) Act (Chapter 309) Singapore Parliament. 1993.

81 Landman A. Push or be punished: tobacco industry documents reveal aggression against businesses that discourage tobacco use. Tobacco Control 2000;9:339-46.

82 Choo L. Industry sponsored YSP: [email to M. Assunta]. 12 Jul 2004. 